21 (1), 2020, 22-34
Jurnal Pendidikan MIPA
e-ISSN: 2550-1313|p-ISSN: 2087-9849
http://jurnal.fkip.unila.ac.id/index.php/jpmipa/

\title{
Students' Performance on Inquiry-Based Physics Instruction through Virtual Simulation
}

\author{
John Salazar Eviota, Minnie Maliwat Liangco
}

Department of Education, Pampanga State Agricultural University, Philippines

\begin{abstract}
The main goal of this study was to prove the effect of inquiry-based instruction through virtual simulation on students' performance in Physics. Three heterogeneous classes at grades seven with 141 students participated in the research, and a quasi-experimental design with pretest and posttest was used. The participants were divided into three groups for the three different teaching strategies, such as; inquiry-based instruction, virtual simulation, and inquirybased instruction through virtual simulation taught by the same teacher. The pretest and posttest scores of the three groups were analyzed using comparative analysis, an F-test to determine if there is a significant difference in the students' performance in learning the Physics concept before and after applying the inquiry-based method and virtual simulation strategy of teaching. The same was used to compare the difference between their performance before and after using inquiry-based instruction through virtual simulation. The findings revealed that inquiry-based instruction caused satisfying acquisition of scientific concepts related to content taught in Physics. The outcomes also supported that all the three teaching strategies have a highly notable effect on the students' performance in Physics. As a result, the inquiry-based instruction through virtual simulations had a potential to help grade seven students improve their performance in Physics.
\end{abstract}

Keywords: inquiry-based instruction, virtual simulations, Physics teaching.

Abstrak: Tujuan penelitian ini adalah untuk membuktikan pengaruh pembelajaran berbasis inkuiri melalui simulasi virtual pada kinerja siswa dalam pembelajaran Fisika. Tiga kelas yang heterogen dengan 141 siswa berpartisipasi dalam penelitian kuasi-eksperimental dengan pretest dan posttest. Para peserta dibagi menjadi tiga kelompok untuk tiga strategi pembelajaran yang berbeda yaitu: pembelajaran berbasis inkuiri, simulasi virtual, dan pembelajaran berbasis inkuiri melalui simulasi virtual. Skor pretest dan posttest dari ketiga kelompok dianalisis menggunakan analisis komparatif dengan uji-F untuk menentukan apakah ada perbedaan yang signifikan dalam kinerja siswa sebelum dan sesudah menerapkan pembelajaran berbasis inkuiri, simulasi virtual, dan pembelajaran berbasis inkuiri melalui simulasi virtual. Temuan mengungkapkan bahwa pembelajaran berbasis inkuiri memberikan hasil yang memuaskan dari konsep-konsep ilmiah terkait dengan konten yang diajarkan dalam Fisika. Hasil juga mendukung bahwa ketiga strategi pengajaran memiliki dampak yang sangat signifikan pada kinerja siswa dalam Fisika. Pada akhirnya, pembelajaran berbasis inkuiri melalui simulasi virtual memiliki potensi untuk membantu meningkatkan kinerja siswa kelas tujuh pada pengajaran Fisika.

Kata kunci: pembelajaran berbasis inkuiri, simulasi virtual, pengajaran Fisika.

John Salazar Eviota

Email: john.eviota@ deped.gov.ph
DOI: http://dx.doi.org/10.23960/jpmipa/v21i1.pp22-34

Received: 21 March 2020

Accepted: 23 June 2020 


\section{- INTRODUCTION}

Learning Science is doing Science. Learners in the $21^{\text {st }}$ century who are noted to be 'naturally-born investigators' learn best in Science through hands-on and minds-on learning situations that foster their inquisitiveness and enable them to apply the different process skills in doing Science. Hence, Science education should be focused in providing learners with active learning experiences that will equip them with knowledge and skills, eventually leading them to scientific and technological innovations (Gutierrez, 2015). This fact prompts the Department of Education in the country to initiate a major curriculum reform which led to the implementation of the Enhanced Basic Education Curriculum that is geared towards the development of scientific and technological literacy among learners through the use of constructivist, learner-centered and inquiry-based approach in teaching that would stimulate their inquisitiveness, leading them to discovery and enabling them to realize the relevance of Science in their lives (Department of Education, 2016; Department of Education, 2012). One of the teaching strategies under the inquiry approach prescribed by the curriculum is the Engage, Explore, Explain, Elaborate \& Evaluate (5E's) learning cycle because it allows learners to generate a conceptual understanding of the subject through inquiry and investigations (Sen \& Oskay, 2017; Abdi, 2014). However, many teachers are less confident and hesitant in using this strategy because of the challenges associated in its implementation which resort them to the old way of teaching the subject (Gutierez, 2015; Skamp \& Peers, 2012) where facts are given much focus rather than the development of scientific skills, thus, producing learners with low level of interest in Science (Bernardo, Limjap, Prudente \& Roleda, 2008; Khalid \& Azeem, 2012).

In 2013 by virtue of the Republic Act 10533, section 5 of the Curriculum Development state that the curriculum shall use pedagogical approaches that are constructivist, inquiry-based, reflective, collaborative and integrative (DepEd, 2013). To achieve the goal in improving the students' performance in science, Philippine education system greatly emphasizes the use of inquiry-based instruction to nurture the next generation of scientists, engineers, and medical professionals to contribute to the country's growth and development (Montebon, 2014). Aside from the utilization of inquiry-based instructions, the Department of Education envisions an ICT-supported system of quality basic education which includes the use of virtual simulations in teaching science concepts (Bonifacio, 2013).

The learning cycle is an inquiry-based instructional strategy which was introduced in the Science Curriculum Improvement Study (SCIS) in the late 1950's by Atkin \& Karplus (Bybee, 2014; Abraham, 2017). Originally, the learning cycle consists of three phases namely: exploration, where learners are given the opportunity to engage in investigations about different Science concepts; concept introduction, where students are given a chance to construct Science concepts based on their investigation; and lastly concept application, where learners are given the opportunity to apply the concept they learned in their daily lives (Brown \& Abell, 2007).

Over the years, the learning cycle had been modified and one of its modification commonly used today is the 5 E's learning cycle, an instructional model that is used to challenge students' pre-existing knowledge including their misconceptions about a certain concept and reconstruct their conceptions through investigations (Bybee, 2014). The 5 E's learning cycle which consists of five phases namely; engage, explore, explain, elaborate and evaluate is aligned in the constructivist point of view that learners are capable of constructing their own learning through their experiences (Chola \& Sumba, 
2016). Madu \& Amaechi (2012) expounded each phase of the learning cycle. In the engage phase, the learners' attention is captured, and their prior knowledge is evaluated by the teacher while the exploration part allows learners to engage in an investigation to solve a problem. In the explanation phase, the concepts identified by the learners in the exploration part will be reinforced through a discussion facilitated by the teacher for the learners to have an in-depth understanding of the concept while the elaboration part will allow the learners to apply the scientific concepts they learned to their daily lives. The last phase which is the evaluation part aims to assess learners' conceptual understanding and progress.

Although the use of 5 E's learning cycle is proven to be effective in facilitating an inquiry-based classroom and effective in enhancing students' achievement in Science (Bybee, 2014; Duran \& Duran 2004), still there are teachers who are hesitant to use it because of the challenges that are associated in its implementation. One of the challenges in using this strategy is its nature of being time-consuming (Skamp \& Peers, 2012). Each phase of the learning cycle must be carried out in an ample amount of time because it is specifically intended to work at its best in a lesson which is good for two to three weeks of discussion and not for a single-day lesson (Bybee, 2014). Furthermore, according to Bybee (2014), employing this learning cycle in a single-day lesson may decrease its efficiency for the reason that a shorter time will be allotted in doing each phase of the cycle. This nature of the learning cycle of being time-consuming appears to be the primary culprit why in the study conducted by Gutierez (2015), it was revealed that teachers who employed inquiry-based approach through the use of the 5E's learning cycle in teaching Science tend to use the traditional method because of the many competencies that are needed to be tackled in a given quarter. It was also revealed that many teachers have a misunderstanding regarding its proper execution, thus, proper training is still needed. Another thing is that this learning cycle will most likely fail if learners' pre-existing knowledge is not thoroughly explored and their misconceptions are not fully identified by the teacher (Balci, Cakiroglus, \& Tekkaya, 2006)

Virtual simulation has been widely used for education and training over the years. It is used as a supplemental teaching tool along with hands-on learning activities (Eskrootchi \& Oskrochi, 2010; Rodrigo, 2010). It has significant effects in boosting the learners' concentration in learning science concepts, especially for laboratory activities. Virtual simulations have enriched the visual presentations of abstract and difficult science concepts. It has a positive effect on the students' comprehension of task inside the laboratory as well as the laboratory skills before and during laboratory activity. It has enriched the visual presentations of abstract and difficult science concept that allow the students to repeat the activity as a manner of review for examinations without costing them much and without wasting any materials at all (Tatli \& Ayas, 2010; Tuysuz, 2010; Bajpai \& Kumar, 2015). Virtual simulations provide an opportunity for students to commit mistakes and correct themselves in preparation for the actual and professional life (Hafner, Hafner, \& Ovtcharova, 2013).

In the Philippine setup, the use of virtual simulation did not entirely change or alter the epistemological beliefs of the Filipino students in learning science concepts. Significant changes were observed in nature of knowing, a learning and real-life applicability only. Student motivation significantly improved. The conceptual understanding of the students increased from low mastery to average mastery level (Mirana, 2016). Virtual simulation is not guaranteed to be attractive most of the time; the levels of its difficulty should match the learners' level, age, and gender. 
One of the new ways of using inquiry-based instruction is with the aid of technology through virtual simulation. It enables the students to formulate hypothesis through data collection that could be proven or rejected upon the progress of class discussion (Boytchev, Stefanova, Nikolova, \& Stefanov, 2014). It has promising evidence that can enhance conceptual perception and understanding, however, the effectiveness in conveying science concepts requires good design, assessments, and proper scaffolding of the learning experience itself (Samur \& Evans, 2011).

Virtual Simulation is at least as effective as a real laboratory. It can maximize interactivity that motivates the students to be active thinker through inquiry-based instruction instead of being passive observer, thus creating a meaningful teachinglearning process (Tatli \& Ayas, 2011). Inquiry-based learning allows the learner to take control over what they are learning in a hands-on activity. Taking this philosophy and incorporating it into a computer simulation can provide even greater enhancement of learning (Roseman \& Jones, 2013; Wilson, 2016).

Using virtual simulation in an inquiry-based class discussion, students and teachers become highly engaged and student attendance improved. The disruptive behavior drops, and students build 21st-century skills in virtual communication and expression. Most importantly, the use of this type of technology in the classroom can facilitate good inquiry teaching (Ketelhut, Nelson, Clarke, Dede, 2010). Although educational virtual environments can support highly interactive inquiry activities and are beginning to be used to deliver inquiry-based science curriculum, there are factors that should be addressed to maximize their effectivity which include the totality of the students, whether all of them can benefit from the experience, and the access to the classroom resources to conduct scientific virtual inquiry-based class (Nelson \& Ketelhut, 2007).

The main purpose of this study was to determine the performance of the participants using inquiry-based instruction through virtual simulation in teaching Physics. Specifically, this study sought to explore how may the performance of the three groups be described in terms of pretest and posttest, the significant difference between the pretest and posttest of the three groups, the significant difference among the performances of the three groups, and how do these three teaching interventions affect the students' performance in Physics.

\section{- METHOD}

This research is a quasi-experimental study which includes pretest and posttest design with the control group and experimental group (Abdi, 2014). The independent variable in this study was the teaching method used in grade seven Physics classes. Intact treatment groups were randomly selected to receive inquiry-based instruction, virtual simulation, and the combination of inquiry-based approach through the virtual simulation of teaching. The dependent variable in this study was the students' performance on inquiry-based instruction, virtual simulation and the combination of inquiry-based approach through virtual simulation.

\section{Instruments}

The pretest and posttest that was utilized in the study was the pretest and posttest available in Science Learners Module of grade 7. The pretest consisted of 24 multiplechoice questions (Asuncion, Catris, Maramag, \& Morales, 2012), which consisted of picture analysis computations and table analysis, while the posttest consisted of 24 
multiple-choice questions (Asuncion et al., 2012), which also consisted of picture analysis, computations and table analysis.

The competencies were based on the Curriculum Guide in Science 7. The questions covered the topics of Motion, Waves, Sounds and Light (Asuncion et al., 2012). The pretest and posttest coming from the Teacher's Guide Grade Seven Science were subjected to content validation specifically the use of Table of Specification. Initially, it was presented to eight science teachers and one head teacher in science. They were requested to assess the clarity, specificity, and sufficiency of items. Thereafter, their suggestions were incorporated into the final draft of the instrument. The test items were arranged according to the table of specifications based on the competencies of the topics taught during the course of the study.

\section{Procedure}

The first group was taught using the inquiry-based instruction through 5E model namely: Engage, Explore, Explain, Elaborate, and Evaluate. The engaging part served as the motivation part which was in the form of challenging questions or problems for the students to answer using their pre-existing knowledge. During the exploration phase, the students performed some activities or experiments which allowed them to identify the concept of the activity. In the next part, which was the explanation part, the students explained the concepts they had identified and discussed them in the class. The next part was the elaboration part, in which the teacher introduced the concept learned by the students in a new context particularly in their daily lives to give them a broader understanding of the concept. The last part of the discussion was the evaluation part wherein the teacher was given a chance to assess students' learning.

The second group was taught using the combination of inquiry-based instruction through virtual simulation. The engaging part served as the motivation which was carried out in the form of challenging questions or problems to test their pre-existing knowledge. During the exploration phase, the students performed pre-simulation activity, in which the students were able to explore the navigation process and features of the virtual simulation. In the next part, which was the explanation part, the students explained the concepts they had identified and discussed them using virtual simulation. The next part was the elaboration part, in which the teacher introduced the problem which was solved by the students using special functions of the virtual simulation. The last part of the discussion was the evaluation part wherein the teacher was given a chance to assess students' learning.

The third group was taught using the virtual simulation. This group started the learning process through pre-simulation activity, an orientation activity on how to use the simulation. The class discussion was carried out through the use of series of virtual simulations. The students were given the chance to answer the guide questions and solve the situational problem through the use of virtual simulation. The students were also given a post-simulation activity to assess the level of understanding after conducting the experiment using the virtual simulation.

Thereafter, the researcher administered the posttest to the groups of inquirybased instruction, virtual simulation, and inquiry-based instruction through virtual simulation. The data that was collected from the pretest and posttest and was treated statistically to determine the significant difference in the students' performance in learning Physics concept before and after using an inquiry-based method and virtual simulation. The same action was done to compare the difference between their 
performance before and after using inquiry-based instruction through virtual simulation. To analyze the data, the Statistical Package for Social Sciences (SPSS) was utilized. Mean and standard deviation were used to determine the performance in Physics concept of the grade 7 students before and after applying inquiry-based instruction, virtual simulation method and inquiry-based instruction through virtual simulation. After which, the pretest and posttest scores of the three groups were analyzed using a comparative analysis, an F-test to determine if there is a significant difference in the students' performance in learning the Physics concept before and after applying the inquiry-based method, virtual simulation strategy of teaching, and inquiry-based instruction through virtual simulation.

\section{- RESULT AND DISCUSSION}

Table 1 illustrates the pretest scores of the three groups. Groups who are within the 11-14 numerical ratings show an outstanding performance in the pretest, 8-10 ratings demonstrate very satisfactory performance, 5-7 scores display a satisfactory performance, 2-4 ratings exemplify a fairly satisfactory performance, while 0-1 ratings indicate poor performance in the pretest. In the pretest results of the inquiry-based instruction through virtual simulation, the group obtained a satisfactory rating with a mean score of 6.53 and a standard deviation of 2.55. In the pretest result of the group under inquiry-based instruction, the group attained a satisfactory rating with a mean score of 6.19 and a standard deviation of 2.67, while the group under virtual simulation also achieved a satisfactory rating with a mean score of 5.29 and a standard deviation of 2.54 .

Table 1. Pretest scores of the three groups of student-participants

\begin{tabular}{cccc}
\hline \multirow{2}{*}{ Scores } & \multicolumn{3}{c}{ Groups } \\
\cline { 2 - 4 } & $\begin{array}{c}\text { Inquiry-Based Instruction } \\
\text { through Virtual Simulation }\end{array}$ & $\begin{array}{c}\text { Inquiry-Based } \\
\text { Instruction }\end{array}$ & $\begin{array}{c}\text { Virtual } \\
\text { Simulation }\end{array}$ \\
\hline $2-4$ & 11 & 15 & 24 \\
$5-7$ & 22 & 17 & 15 \\
$8-10$ & 9 & 13 & 9 \\
$11-15$ & 3 & 2 & 1 \\
\hline Mean & $\mathbf{6 . 5 3}$ & $\mathbf{6 . 1 9}$ & $\mathbf{5 . 2 9}$ \\
SD & $\mathbf{2 . 5 5}$ & $\mathbf{2 . 6 7}$ & $\mathbf{2 . 5 4}$ \\
DR & $\mathbf{S}$ & $\mathbf{S}$ & $\mathbf{S}$ \\
\hline
\end{tabular}

Overall, the results showed that the three groups of students had statistically equivalent basic knowledge before participating in these learning activities. These results support the findings of Sagner (2008), Maxwell, Lambeth, Cox (2014), Srisawasdi \& Punjaburee (2015), and Sari, Hassan, Guven, Sen (2017), that the levels of conceptual understanding of the students in Speed, Waves, Sound and Light in all groups were on the same level. It was emphasized that students are expected to be at the same level of understanding the concepts before undergoing any treatments; thus, the students exemplify least prior knowledge about the lesson.

Table 2 reveals the posttest scores of the three groups. Groups who are within the 18-23 numerical ratings show an outstanding performance in the posttest, 12-17 ratings demonstrate very satisfactory performance, 7-11 scores display a satisfactory 
performance, 2-6 ratings exemplify a fairly satisfactory performance, while 0-1 ratings indicate poor performance in the pretest. In the posttest results of the inquiry-based instruction through virtual simulation, the group obtained a satisfactory rating with a mean score of 10.60 and a standard deviation of 3.40. On the other hand, the group under inquiry-based instruction attained a very satisfactory rating with a mean score of 11.87 and a standard deviation of 4.69 , while the results of the group under virtual simulation achieved a satisfactory rating with a mean score of 7.47 and a standard deviation of 3.84 during the posttest.

Table 2. Posttest Scores of the three groups of student-participants

\begin{tabular}{cccc}
\hline \multirow{2}{*}{ Scores } & \multicolumn{3}{c}{ Groups } \\
\cline { 2 - 4 } & $\begin{array}{c}\text { Inquiry-Based Instruction } \\
\text { through Virtual Simulation }\end{array}$ & $\begin{array}{c}\text { Inquiry-Based } \\
\text { Instruction }\end{array}$ & $\begin{array}{c}\text { Virtual } \\
\text { Simulation }\end{array}$ \\
\hline $2-6$ & 2 & 5 & 18 \\
$7-11$ & 26 & 21 & 24 \\
$12-17$ & 17 & 14 & 5 \\
$18-23$ & 0 & 7 & 1 \\
\hline Mean & $\mathbf{1 0 . 6 0}$ & $\mathbf{1 1 . 8 7}$ & $\mathbf{7 . 4 7}$ \\
SD & $\mathbf{3 . 4 0}$ & $\mathbf{4 . 6 9}$ & $\mathbf{3 . 8 4}$ \\
DR & $\mathbf{S}$ & VS & $\mathbf{S}$ \\
\hline
\end{tabular}

In the study conducted by Blyth (2010), it is evident that the student' performance after being taught using inquiry-based instruction through virtual simulation has improved the performance significantly. Furthermore, the results also support the findings of Sari Ay \& Yilmaz (2015) and Korr (2013) that the mean score of the posttest of the virtual simulation group is significantly higher than the pretest. Thus, the mean scores of all groups were increased to some degrees from pretest to posttest. The group under inquiry-based instruction obtained most improvement based on the students' performance in posttest while the group under virtual simulation reveals the least improvement on the students' performance based on the posttest results. Overall, according to the outcomes of the posttest of each group, students' performance has improved considering their scores from pretest to posttest

Table 3 shows the difference between the performance on the pretest and posttest of each group. Inquiry-based instruction through virtual simulation obtained a mean score of -4.07 with a standard deviation 3.37 at $1 \%$ level of significance between the results of the pretest (6.53) and the posttest (10.60). Inquiry-based instruction attained a mean score of -5.68 with a standard deviation of 4.82 at $1 \%$ level of significance between the results of the pretest (6.19) and the posttest (11.87). In the case of virtual simulation, the group achieved -2.18 mean score with a standard deviation of 3.86 at $1 \%$ level of significance between the results of the pretest (5.29) and the posttest (7.47).

Table 3. Difference between the pretest and posttest of the three groups of studentparticipants

\begin{tabular}{cccc}
\hline Groups & Mean & $\begin{array}{c}\text { Std. } \\
\text { Deviation }\end{array}$ & Remarks \\
\hline $\begin{array}{c}\text { Inquiry-Based Instruction through } \\
\text { Virtual Simulation }\end{array}$ & -4.07 & 3.37 & $\begin{array}{c}\text { Significant at } \\
1 \%\end{array}$
\end{tabular}




\begin{tabular}{cccc}
\hline $\begin{array}{c}\text { (Pretest vs Posttest) } \\
\text { Inquiry-Based Instruction } \\
\text { (Pretest vs Posttest) }\end{array}$ & -5.68 & 4.82 & $\begin{array}{c}\text { Significant at } \\
1 \%\end{array}$ \\
$\begin{array}{c}\text { Virtual Simulation } \\
\text { (Pretest vs Posttest) }\end{array}$ & -2.18 & 3.86 & $\begin{array}{c}\text { Significant at } \\
1 \%\end{array}$ \\
\hline
\end{tabular}

The results showed were similar to the study conducted by Rutten, Van Der Veen, \& Van Joolingen (2012) about the Physics of sound wave properties in integrating computer-based laboratory with inquiry-based instruction. The group obtained a significant increase in scores during the posttest as compared with the pretest result. In connection with inquiry-based instruction, the results were consistent with the study conducted by Kimberlin \& Yezierski (2016), testing the effectiveness of inquirybased instruction using particle level models to junior high school students. The group yielded a significant difference between the pretest and posttest results. On the other hand, the results obtained by the group under virtual simulation is in contrary to the results obtained by the study conducted by Asiksoy \& Islek (2017), the current study revealed a significant difference between the performance in the pretest and posttest while the previous study showed no significant difference in pretest and posttest results. Overall, the three groups showed a significant difference in their performances between the pretest and the posttest. The mean scores implied that all groups attained higher scores during the posttest then the pretest. The three groups showed improvement in the students' performance after the treatment.

Table 4 revealed the difference between the pretest and posttest scores of the three groups. The pretest and posttest results between the inquiry-based instruction and inquiry-based instruction through virtual simulation obtained a mean difference of 1.27 with a p-value of 0.131 which showed no significant difference in the students' performances.

Table 4. The difference among the performances of the three groups of studentparticipants IBI, VS, IBIVS are Inquiry-Based Instructions, Virtual Simulations, and Inquiry-Based Instructions through Virtual Simulations respectively.

\begin{tabular}{cccc}
\hline Variables & Mean Difference & p -value & Remarks \\
\hline IBI vs IBIVS & 1.27 & 0.131 & Not Significant \\
IBI vs VS & 4.4030 & 0.000 & Significant at $1 \%$ \\
VS vs IBIVS & 3.1306 & 0.000 & Significant at $1 \%$ \\
\hline
\end{tabular}

The outcome supports the results in the study conducted by Mustafa \& Trudel (2013); this study reveals that the results are incomparable when it comes to the performance between the groups under inquiry-based instruction and inquiry-based instruction through virtual simulation respectively. This implies that the two groups had a statistically equal level of conceptual understanding after participating in these learning strategies.

The pretest and posttest results of the groups under inquiry-based instructions and virtual simulation attained a mean difference of $4.4030^{*}$ and a p-value of 0.000 at $1 \%$ level of significance which means there was a highly significant difference in terms of performance between their pretest and posttest scores. The results agree with the findings of the study conducted by Mustafa \& Durmus (2009) that students' performance through inquiry-based instruction and virtual simulation increased to some 
degrees from pretest to posttest. The two groups had a statistically the same effect on students' understanding after the treatments. In the groups of virtual simulation and inquiry-based instruction through virtual simulation, the groups obtained a mean difference of 3.1306 and a p-value of 0.000 at $1 \%$ level of significance which means that there was a significant difference between their pretest and posttest scores. The outcomes obtained from the mean difference of the students' performance were statistically significant which supported the study conducted by Gunhaart \& Srisawasdi (2012), Sari Ay \& Yilmaz (2015) and Bumbacher et al. (2015). The virtual simulation applied through inquiry-based instruction has the same effect to conceptual understanding of the students after the treatment as compared to virtual simulation alone. Overall, the results show that the students' performances between the groups under inquiry-based instructions and inquiry-based instruction through virtual simulation have no significant difference in the performance. Based on this outcome, it is implied that the positive effect of inquiry-based instruction towards students' performance is on the same level on the effect of inquiry-based instruction through virtual simulation.

\section{Implication of the three Teaching Interventions to the Students' Performance in Physics}

Several studies have been published citing the effectivity of inquiry-based instruction and virtual simulation as teaching strategies. These techniques are widely used in teaching science concepts ranging from primary to tertiary level of students. Most of the studies have proven the positive effect of inquiry-based instruction to the students' performance in Physics. The results showed that the students were able to develop higher order thinking skills. This teaching strategy has a great advantage to the students since this technique makes them responsible for the amount of knowledge they can grasp during the teaching and learning process. This method requires the students to think and share their ideas about the concept, thus, making them more creative and innovative in collecting data in formulating their outputs. On the part of the teacher, this teaching strategy lessens their burden in executing the lesson since they function as the facilitator of the learning process. The students shall accomplish all of the activities and the teachers' role is to guide the students and process their ideas leading to the right and exact development of the concept. Inquiry-based instructions can help improve not only the students' performance in Physics but in the students' achievement in science as a whole.

On the other hand, the same effects have been found out with virtual simulation. It enriches the visual presentations of abstract and difficult science concepts and provides an opportunity for students to commit mistakes and correct them themselves. The use of virtual simulations in science instruction is suitable, especially when the content of science is taken into consideration. Among the reasons for this suitability is that allowing the students to use computer software enriched with visual presentations makes difficult and abstract scientific concepts and principles concrete and understandable. This strategy also helps the students to explore concepts in the absence of the actual laboratory apparatus without risking the quality and the amount of knowledge that they can get from the lesson. However, the use of virtual simulation is not beneficial in all students at all times. One of the challenges encountered during the course of the study was the availability of the accessible desktop computers that can accommodate students all at the same time. Not all government schools have enough 
computers to support this teaching strategy. Giving instructions and commands is also one of the challenging encounters during the conduct of the study because not all students have access to computers and World Wide Web at home which results to more time allotment in instruction than accomplishment of the given activities.

Based on the outcome, it is therefore implied that virtual simulation strategy can be more effective as a technique if it is practiced not only at school but also at home. The exposure of the students towards virtual simulation is an essential and integral action to the teaching and learning process. The intervention must be continuous to ensure positive and consistent learning effect on the students' performance. This means that it is essential that students are exposed to virtual simulation not only at school but also in their respective homes.

On the other side, considering the two strategies above mentioned, this study explored the effects in the students' performance through inquiry-based instruction executed using virtual simulation. The students who have been taught using inquirybased instruction through virtual simulation have become more interested in learning science concepts. The students were excited by the simulations' functionality, especially by the possibility to manipulate objects and phenomena. The virtual simulation created an atmosphere in which all the students worked intensively, allowing them to have their own direction, according to personal perception of the activity, in a guided pace. The initial enthusiasm established better conditions for successful inquiry learning activities. After that, the students started the collection of data through subsequent experiments, systematically proving their hypothesis and recording the data and conclusions.

This study offers results that support work previously conducted by other researchers. The results from the previous studies indicated that secondary school students had better conceptual achievement of science by interacting with the inquirybased learning of science by virtual simulation. Active will of students to participate learning activities plays an important role to make learning effective. Although a visual instruction developed by computerized technology with inquiry-based instruction would make a positive contribution to students' achievement in most of the scientific topics and concepts, it is also better to kept in mind that using inquiry-based instruction through virtual simulations alone does not solve any problem. To gain a better result from the education, this strategy must be supported with appropriate instructional methods and software related to the topics and concepts to be taught in the class. The fact is accepted that there is no single best approach, strategy or technique that will suit all types of learners, but in the new system of education, teaching $21^{\text {st }}$ century learners requires teachers to be more creative and innovative in terms of deciding what approaches, strategies and techniques they will be employing inside the classroom.

\section{- CONCLUSION}

Based on the findings of the study, the following conclusions were drawn: The student-participants under inquiry-based instruction, virtual simulation and inquirybased instruction through virtual simulation have the same level of conceptual understanding prior to the treatment and inquiry-based instructions have the greater improvements in the students' performance among the three group. The three groups also show notable improvement in the students' performance as per the results of the pretest and posttest of each group Comparing the overall performance among the three groups, this study reveals that inquiry-based instruction through virtual simulation and inquiry-based instruction shows the same effects in improving students' performance in 
Physics. The use of simulations can positively influence science instruction and Student engagement; thus, inquiry-based science instruction is positively influenced by the use of simulations.

\section{- REFERENCES}

Abdi, A. (2014). The effect of inquiry-based learning method on students' academic achievement in science course, Universal Journal of Educational Research, 2(1), 37-41.

Asuncion A., Catris L., Maramag C., \& Morales M. (2012). Science Teachers' Guide Pasig City, Philippines: Department of Education.

Bajpai, M. \& Kumar, A. (2015). Effect of virtual laboratory on students' conceptual achievement in physics, International Journal of Current Research,7(2), 1280812813.

Blyth, K., (2010).Effectiveness of using inquiry-based instruction to increase students performance in high school biology as bardwell institute, STEM Education and Professional Studies, 46, 1-27.

Bonifacio A., (2013). Developing information communication technology (ICT) curriculum standards for k-12 schools in the philippines, Semantic Scholar, np.

Boytchev, P., Stefanova, E., Nikolova, N. \&Stefanov, K. (2014). A virtual classroom: a pilot case in inquiry-based learning, Proceedings of the $6^{\text {th }}$ International Conference on Computer Supported Education, 264-269.

Brickman, P., Gormally, C., Armstrong, N., Hallar, B. (2009). Effects of inquiry-based learning on students' science literacy skills and confidence, International Journal for the Scholarship of Teaching and Learning, 3(16), 1-22.

Bybee, R. (2014). The BSCS 5E instructional model: personal reflections and contemporary implications, Science and Children, 3(5), 10 - 13.

Department of Education. (2013). DO 43, s. 2013 -Implementing rules and regulations (irr) of republic act no. 10533 otherwise known as the enhanced basic education act of 2013, Retrieved from http://www.deped.gov.ph/orders/do-43-s-2013.

Eskrootchi, R., \&Oskrochi, G. R. (2010).A study of the efficacy of project based learning integrated with computer-based simulation - STELLA, Educational Technology and Society, 13 (1), $236-245$.

Gutierrez, S. B. (2015). Bridging the challenges of inquiry-based teaching: commonwealth elementary school teachers' insights on lesson study. Retrieved from:http://lessonstudy.nismed.upd.edu.ph/2015/05/-inquiry-basedteaching.html

Gutierez, S. B. (2015). Collaborative professional learning through lesson study: identifying the challenges of inquiry-based teaching, Issues in Educational Research, 25(2), 118-133.

Hafner, P., Hafner, V., \& Ovtcharova, J. (2013). Teaching methodology for virtual reality practical course in engineering education, Procedia - Computer Science, $25,251-260$.

Samur, Y., \& Evans, M. A. (2011). Learning science through computer games and simulations - Edited by Margaret A Honey \& Margaret Hilton. British Journal of Educational Technology, 42(6),171-172.

Ketelhut, D., Nelson, B., Clarke, J., \&Dede, C. (2010). A multi-user virtual environment for building higher order inquiry skills in science, British Journal of Educational Technology, 41(1), 56-68. 
Kimberlin, S., \&Yezierski, E. (2016).Effectiveness of inquiry-based lessons using particulate level models to develop high school students' understanding of conceptual stoichiometry, Journal of Chemical Education, 93(6), 1002 - 1009.

Korr, A.H. (2013). Use of specific web-based simulations to support inquiry-based high school science instruction, Retrieved from: http://digitalcommons.unf.edu/etd/ 474.

Maxwell, D.O., Lambeth, D.T., \&Cox J.T. (2015).Effects of using inquiry-based learning on science achievement for fifth-grade students, Asia-Pacific Forum on Science Learning and Teaching, 16(1), 1-28.

Merchant, Z., Goetz, E., Cifuentes, L., Keeney-Kennicutt, W., \&Davis, T. (2014). Effectiveness of virtual reality-based instruction on students' learning outcomes in K-12 and higher education: A meta-analysis, Computers and Education, 70, $29-40$.

Mirana, V. P. (2016).Effects of computer simulations and constructivist approach on students' epistemological beliefs, motivation and conceptual understanding in physics, International Conference on Research in Social Sciences, 89-93.

Montebon, D. T. (2014). K12 science program in the Philippines: student perception and its implementation, International Journal of Education and Research, 2(12), 153-164.

Mustafa, B., \&Durmus, S. (2009).The effectiveness of computer supported versus real laboratory inquiry learning environments on the understanding of direct current electricity among pre-service elementary school teachers, Eurasia Journal of Mathematics, Science \& Technology Education, 6(1), 47-61.

Mustafa, M.I., \&Trudel, L. (2013). The impact of cognitive tools on the development of the inquiry skills of high school students in physics, International Journal of Advanced Computer Science and Applications, 4(9), 124-129.

Nelson, B. C., \&Ketelhut, D.J. (2007). Scientific inquiry in educational multi-user virtual environments, Educational Psychology Review 19, 265-283.

Rodrigo, M. T. (2011). Dynamics of students cognitive-affective transition during a mathematics game, Simulation and Gaming, 42(1), 85-99.

Roseman, R. B., \& Jones, D. L. (2013). Utilization of hands-on and simulation activities for teaching middle school lunar concepts. AIP Conference Proceedings, 1513, 346-349.

Rutten, N., van Joolingen, W.R., \& van der Veen, J.T. (2012). The learning effects of computer simulations in science education, Computers and Education, 58(1), $136-153$.

Sari Ay, O., \&Yilmaz, S. (2015). Effects of virtual experiments-oriented science instruction on students' achievement and attitude, Elementary Education Online, 14(2), 609-620.

Sari, U., Hassan, A. H., Guven, K, \&Sen, O.F. (2017). Effects of the 5E teaching Model using interactive simulation on achievement and attitude in physics education, International Journal of Innovation in Science and Mathematics Education, 25(3), 20-35.

Srisawasdi, N., \&Panjaburee, P. (2015).Exploring effectiveness of simulation-based inquiry learning in science with integration of formative assessment, Journal of Computer Education, 2(3), 323-352.

Tatli, Z., \& Ayas, A. (2011). Effect of a virtual chemistry laboratory on students' achievement, Educational Technology and Society, 16(20), 159-170. 
Tatli, Z., \&Ayas, A. (2010). Virtual laboratory education in chemistry education, Procedia - Social and Behavioral Sciences, 9, 938 - 942.

Tuysuz, C. (2010). The effect of the virtual laboratory on students' achievement and attitude in chemistry, International Online Journal of Educational Sciences, 2(1), 37-53.

Wilson, A. (2016). Computer simulations and inquiry-based activities in an 8th grade earth science classroom, AIP Conference Proceedings, 5, 1-33. 